\title{
Inhibition Effect of Mace Extract Microemulsion on Vitamin C Photooxidation in Aqueous Systems
}

\author{
Hasbullah $^{\#}$, Sri Raharjo*, Pudji Hastuti* \\ \# Faculty of Agricultural, Khairun University, Ternate, 97719, Indonesia \\ E-mail:bullah_has@yahoo.co.id
}

*Faculty of Agricultural Technology, Gadjah Mada University, Yogyakarta, Indonesia

\begin{abstract}
Photooxidation in food systems cause nutritional losses and produces undesirable flavor, toxic and color compounds, which make foods less acceptable or unacceptable to consumers. The objective of this research was to know the effectiveness of mace extract microemulsion to inhibit vitamin $\mathrm{C}$ photooxidation in aqueous systems. Aqueous food systems used are both beverage model system and apple juice beverage, where in each system enriched by $100 \mathrm{ppm}$ vitamin $\mathrm{C}$ as substrate and 20 ppm erytrosin as photosensitiser. It is about one percent and two percent of microemulsion that contain mace extract of 0,500 and 750 ppm were added into each of aqueous food system. Inhibition effect of mace extract microemulsion toward vitamin $C$ photooxidation based on the rate of vitamin $\mathrm{C}$ degradation in aqueous food systems that illuminated by fluorescent light with 2000 lux intensity within eight hours. The result indicated the mace extract microemulsion has anti-photooxidation activity and ability to inhibit vitamin $\mathrm{C}$ photooxidation in aqueous systems.
\end{abstract}

Keywords - mace extract; microemulsion; photooxidation

\section{INTRODUCTION}

Oxidation is one of the causes of damage in food systems. It's can occur in two types, namely autooxidation and photooxidation. Photooxidation reaction occurs in the presence of light, atmospheric oxygen $\left({ }^{3} \mathrm{O}_{2}\right)$ and compounds that can act as sensitiser such as chlorophyll, feofitin, porfirin, riboflavin, myglobin and synthetic colorants [1]-[2]. Photooxidation of food system causes nutritional losses and produces undesirable flavor, toxic, and color compounds, which make foods less acceptable or unacceptable to consumers [1], [3]-[4]. The rate of substrate damage caused by photooxidation reaction was 1500 times faster than autooxidation reaction [2]. Photooxidation can be prevented with the use of antioxidant that has ability as quencher. The mechanisms of quencher in inhibition of photooxidation passes through three pathways, which are: excited triplet sensitiser quenching, physically singlet oxygen quenching, and chemically singlet oxygen quenching. Chemically singlet oxygen quenching pass through the reaction between quencher with oxygen singlet resulted oxidated product $\left(\mathrm{QO}_{2}\right)$.

There are researches, have been reported that substances from carotenoid groups have a good ability as quencher [1], [5] - [14]. $\beta$-carotene is one of carotenoid group substances that can inhibit photooxidation in two pathways: one is singlet oxygen quencher $\left({ }^{1} \mathrm{O}_{2}\right)$ and the other is excited sensitiser triplet quencher $\left({ }^{3} \mathrm{Sen}^{*}\right)$. Singlet oxygen quenching in two mechanisms: one is physically quenching with energy transfer from singlet oxygen to $\beta$-carotene, its reaction : ${ }^{1} \mathrm{O}_{2}+{ }^{1} \beta-\mathrm{car} \rightarrow{ }^{3} \mathrm{O} 2+{ }^{3} \beta$-car and the other is chemically quenching with oxidized products forming, its reaction: ${ }^{1} \mathrm{O}_{2}+{ }^{1} \beta$-car $\rightarrow \beta$-car $\mathrm{O}_{2}$ [15]. $\beta$-carotene has been known is a strongest physically quencher in food systems, especially act as a effective singlet oxygen quencher [1]. The ability of $\beta$ carotene related to its structure that has more conjugated diena to release oxygen singlet energy to be calorie [9]-[16].

In our previous research, mace extract it is known contains $\beta$-carotene and phenolic compounds and have a radical scavenging activity. In addition, it can also inhibit the peroxidation of linoleic acid caused by photooxidation (data is not shown). Mace is a part of nutmeg (Myristica fragrans), blanketed shell seeds and colored orange to dark red as shown on Fig. 1 [17]. Mace extract is not water-soluble (hydrophobic) like carotenoid, where it needed a specific technique to help its dispersion when it's applied in aqueous systems or hydrophilic system. 


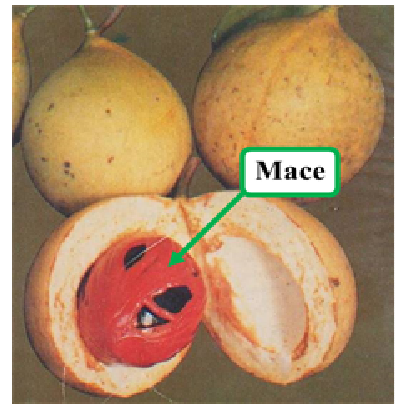

Fig. 1 Mace

The use of oil-in-water $(\mathrm{o} / \mathrm{w})$ microemulsion allows hydrophobic compounds dissolving in a hydrophilic system. Microemulsion is an isotropic dispersion that consisting of oil and water phase, which stabilized by surfactant molecules on surface layer, with help of cosurfactant (usually short chain alcohol for $\mathrm{o} / \mathrm{w}$ microemulsion or poliol for w/o microemulsion), have droplet size of dispersed phase less than $1 \mu \mathrm{m}(5-100 \mathrm{~nm})$, stable to temperature change, transparant, low viscosity and can used as a delivery system of hydrophobic substance in hydrophilic system, conversely, so can increase effectiveness and bioavailability of that substance [18]-[19].

There are many research about photooxidation of vitamin $\mathrm{C}$ in aqueous systems have been done. Reference [20] shows the influence of vitamin $\mathrm{C}$ photooxidation in aqueous model system that containing riboflavin. Where, all of vitamin $\mathrm{C}$ is lost after exposure to light within 12 minutes in the presence of 6 ppm of riboflavin and only $2 \%$ is lost without riboflavin. Fluorescent light has a significant impact on vitamin $\mathrm{C}$ loss of orange juice that stored at ambient temperature $\left(25-30^{\circ} \mathrm{C}\right)$ up to 32 days [21]. Reference [14] shows that the rate of vitamin $\mathrm{C}$ degradation in food aqueous model (composed by $0.045 \%$ vitamin $\mathrm{C}, 6 \%$ sucrose, $1 \%$ citric acid and $92.89 \%$ aquades) and orange beverage model systems wherein each is added $20 \mathrm{ppm}$ erytrosin about $17.9 \mathrm{mg} / \mathrm{L} /$ hour and 11.3 $\mathrm{mg} / \mathrm{L} /$ hour, respectively. Fruit juice beverage is one of complex or heterogeneous aqueous food system, containing vitamin $\mathrm{C}$, but vulnerable to photooxidation effect.

Nonetheless, the study of the ability of mace extract to inhibiting the vitamin $\mathrm{C}$ photooxidation in aqueous systems has not been previously reported. So the objective of this research was to know the effectiveness of mace extract microemulsion to inhibit vitamin $\mathrm{C}$ photooxidation in aqueous systems, both are beverage model system and apple juice beverage that each enriched by $100 \mathrm{ppm}$ vitamin $\mathrm{C}$ as substrate and 20 ppm erytrosin as photosensitiser.

\section{MATERIALS AND METHODS}

\section{A. Materials}

The main material are used in this research, including mace purchased from Marikurubu, Ternate, North Maluku; Tween 80 purchased from Merck (Hohenburnn-Germany); Span 40, Span 80, and ascorbic acid purchased from SigmaAldrich (St. Louis-USA); Aquades, citrate acid, natrium citrate, sucrose (Gulaku), commercial apple juice beverage (Buavita), VCO, and erytrosin purchased from Yogyakarta local market.

\section{B. Production of Mace Extract Microemulsion}

Oil-in-water $(\mathrm{o} / \mathrm{w})$ microemulsion produced by using emulsification methods [18]. Span 80 (low HLB surfactant), Span 40 (medium HLB surfactant) and Tween 80 (high HLB surfactant) were mixed with the VCO as oil phase until homogeneous using hotplate magnetic stirrer (Lab. Companion $\mathrm{HP}-3000$ ) at temperature $70^{\circ} \mathrm{C}$. Aquades as water phase was added by using titration technique. Mixing was performed for 25 minutes. Mace extract microemulsion are made with the same procedure with the $\mathrm{o} / \mathrm{w}$ microemulsion, but mace extract was added before aquadest was added into the mix. mace extract was added into the microemulsion in three concentrations, i.e., 0, 500, and 750

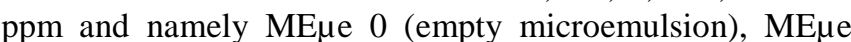

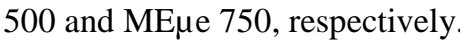

\section{Preparation of Aqueous Systems Sample with Mace Extract Microemulsion}

This research uses 2 types of aqueous food systems, the beverage model system (made from citric buffer $\mathrm{pH} 3.1$ and $6 \%$ sucrose) and the commercial apple juice. Each of those systems enriched by $100 \mathrm{ppm}$ of vitamin $\mathrm{C}$ as substrate and $20 \mathrm{ppm}$ erytrosin as a photosensitiser. Into the sample added $1 \%$ or $2 \%$ ME $\mu$ e, so that the obtained sample with $1 \%$

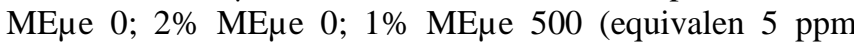

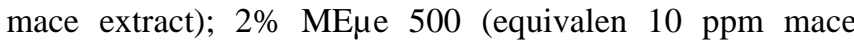
extract); 1\% ME $\mu$ e 750 (equivalen $7.5 \mathrm{ppm}$ mace extract)

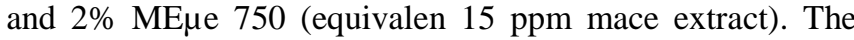
next, sample was placed in a $10 \mathrm{~mL}$ serum bottle and covered with airtight cover. As a control, use the sample with $10 \mathrm{ppm}$ and $15 \mathrm{ppm}$ mace extract being added directly and also the sample without mace extract and microemulsion.

\section{Determination of Inhibition Effect of Mace Extract Microemulsion on Vitamin C Photooxidation in Aqueous Systems}

The inhibition effect of ME$\mu \mathrm{e}$ was done by placing a sample in a light box (size $70 \times 50 \times 60 \mathrm{~cm}^{3}$, which is equipped with 3 cool white fluorescent low UV radiation Osram lamp 18 Watt) under light (sample bottle covered by aluminium foil) and in dark (sample bottle without covered by aluminium) storage conditions. The next, sample was illuminated by fluorescent light with intensity of 2000 lux. The vitamin $C$ content of the sample was measured every 2 hours during 8 hours by photodynamic UV methods [20]. The principle of this method is the oxidation of vitamin $\mathrm{C}$ of sample that containing erytrosin (photosensitiser) with fluorescent light. Then, the sample absorbance is measured at a wavelength of $265 \mathrm{~nm}$ using Shimadzu UV Spectrophotometer pc 1650, before and after illumination. The standard curve was made for quantifying the levels of vitamin $\mathrm{C}$ in the sample.

The rate of vitamin $\mathrm{C}$ degradation was determined by making a curve is the relationship between the illumination time ( $\mathrm{x}$ axis) and the vitamin $\mathrm{C}$ content (y axis). The value of slope is the rate of degradation of vitamin $C$. The smaller value of the slope, the greater of the inhibition effect. 


\section{E. Statistical Analysis}

Results were statistically analyzed by using Analysis of Variance and then tested with LSD on alpha significantly 0.05 to compare the results among treatments.

\section{RESULTS AND DISCUSSION}

\section{A. Effect of Mace Extract Microemulsion to Inhibit Vitamin $C$ Photooxidation in Beverage Model System}

Decrease of vitamin $\mathrm{C}$ content in aqueous systems influenced by the presence of light and erytrosin as a photosensitiser. Erytrosin was added into the systems with an amount of $20 \mathrm{ppm}$ as photosensitiser. Besides its water soluble, erytrosin was chosen in this research because of some carotenoid substances will have the ability as singlet oxygen quencher and excited triplet sensitiser in system contained erytrosin than chlorophyll as sensitiser, where carotenoid substances only can act as singlet oxygen quencher [11]- [21].

Fluorescent light has a significant influence on vitamin $\mathrm{C}$ damage in orange juice that stored at ambient temperature (25-30oC) within 32 days [22]. Loss of vitamin C in milk that exposure by sunlight within 60 minutes and fluorescent light with wavelength $400-550 \mathrm{~nm}$ within 24 hours about $80-100 \%$ and 80-90\%, respectively [1]. Effect of fluorescent light-illumination toward vitamin $\mathrm{C}$ content of beverage model system that contained mace extract microemulsion as showed in Fig 2. The results showed that vitamin $\mathrm{C}$ content in the beverage model systems stored under light and dark conditions were decreasing. While, decreasing of vitamin $\mathrm{C}$ content in beverage model system samples stored in dark condition (covered by alumunium foil) more less than sample stored under light condition (without covered by aluminium foil). Its stressing that photooxidation reaction also needs light, besides sensitiser [1]-[2]. Thus, vitamin $\mathrm{C}$ degradation in beverage model systems samples stored under light condition caused by photooxidation reaction, meanwhile in dark condition caused by autooxidation reaction.

Purpose of quencher is a good method to decrease loss of nutrition in food because of these substances have ability to decrease oxidation by singlet oxygen [1]. The natural compounds in foods such as tocopherol, carotenoid and ascorbic acid can act as effective singlet oxygen quencher [9]-[23]. The inhibition effect of mace extract microemulsion on vitamin $\mathrm{C}$ photooxidation in beverage model systems showed in Table 1 . The rate of vitamin $C$ degradation in samples that contained mace extract microemulsion is lower than controls at light storage condition $(\mathrm{P}<0.05)$. The anti-photooxidation activity of mace extract microemulsion in beverage model system is assumed because of the presence of mace extract that has been known contained of antioxidant from carotenoid ( $\beta$-carotene) and phenolic groups. Reference [11] shows that above $1.86 \times 10$ ${ }^{6} \mathrm{M}$ (1 ppm) of $\beta$-carotene showed an activity as singlet oxygen quencher in soybean oil model system in acetone solvent with FD\&C Red No 3 (erytrosin) as sensitiser, and up to $3.72 \times 10^{-6} \mathrm{M}(2 \mathrm{ppm})$ can act as singlet oxygen quencher and also triplet erytrosin photosensitiser excited quencher. $\beta$-carotene has proven as an effective singlet oxigen quencher in soybean oil that contained chlorophyll as a photosensitiser [6]; in vitamin D2 that contained riboflavin as a photosensitiser [9]; and in soy bean oil that has erytrosin as photosensitiser [11] with quenching rate are $4.60 \times 10^{9} \mathrm{M}^{-}$ ${ }^{1} \mathrm{~S}^{-1} ; 5 \times 10^{9} \mathrm{M}^{-1} \mathrm{~S}^{-1}$; dan $7.3 \times 10^{9} \mathrm{M}^{-1} \mathrm{~S}^{-1}$, respectively.

(A)

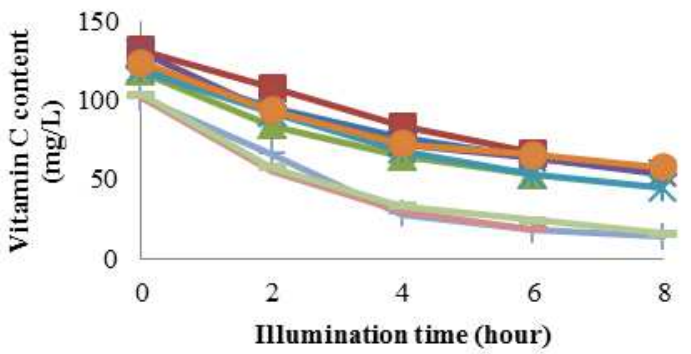

(B)

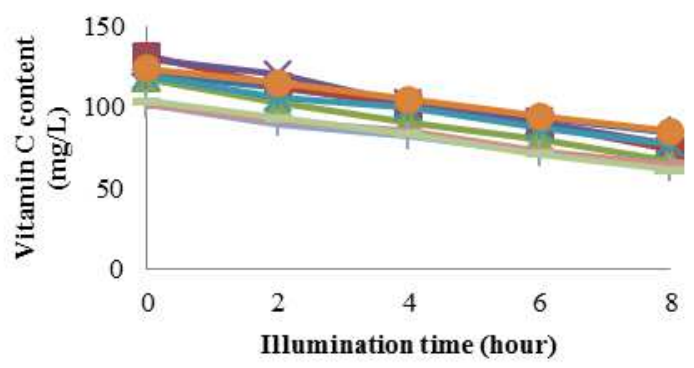

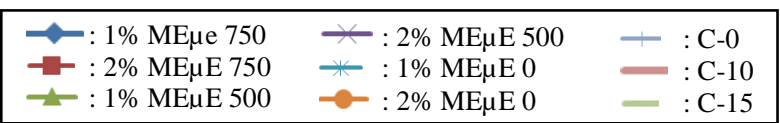

Fig. 2 The effects of fluorescent light-illumination on vitamin $\mathrm{C}$ content of beverage model systems that contained mace extract microemulsion stored under light (A) and dark (B) condition.

TABLE I

InHibition EFFECT OF MACE EXTRACT Microemulsion ON Vitamin C PHOTOOXIDATION IN BEVERAGE MODEL SYSTEMS

\begin{tabular}{|c|c|c|}
\hline \multirow{2}{*}{$\begin{array}{c}\text { Beverage Model System } \\
\text { Samples }\end{array}$} & \multicolumn{2}{|c|}{$\begin{array}{c}\text { Rate of Vitamin C Degradation } \\
(\mathrm{mg} / \mathrm{L} / \mathrm{hour})\end{array}$} \\
\hline & Light (A) & Dark (B) \\
\hline 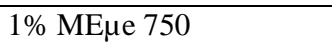 & $8.322 \pm 0.071^{b}$ & $4.528 \pm 0.068^{\mathrm{a}}$ \\
\hline 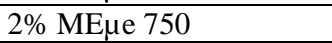 & $10.980 \pm 0.044^{\mathrm{g}}$ & $6.950 \pm 0.050^{\mathrm{g}}$ \\
\hline $1 \%$ МEце 500 & $10.703 \pm 0.093^{f}$ & $6.173 \pm 0.116^{\mathrm{e}}$ \\
\hline $2 \%$ МЕце 500 & $8.999 \pm 0.052^{\mathrm{c}}$ & $6.727 \pm 0.053^{f}$ \\
\hline $1 \%$ MEนе 0 & $9.406 \pm 0.060^{d}$ & $5.137 \pm 0.084^{c}$ \\
\hline 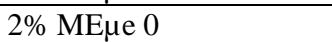 & $7.993 \pm 0.105^{\mathrm{a}}$ & $4.897 \pm 0.055^{b}$ \\
\hline $\mathrm{C}-0$ & $11.130 \pm 0.075^{\mathrm{h}}$ & $4.824 \pm 0.035^{\mathrm{b}}$ \\
\hline $\mathrm{C}-10$ & $13.667 \pm 0.155^{\mathrm{i}}$ & $4.620 \pm 0.058^{\mathrm{a}}$ \\
\hline $\mathrm{C}-15$ & $10.437 \pm 0.050^{\mathrm{e}}$ & $5.378 \pm 0.166^{d}$ \\
\hline
\end{tabular}

Different letters on the column were significant at 0.05 . Results are the mean \pm SD of at least three replicates.

Inhibition effect on vitamin $\mathrm{C}$ photooxidation in beverage model systems also supported by the purpose of $\mathrm{o} / \mathrm{w}$ microemulsion as a delivery system for mace extract that has a hydrophobic character in beverage model systems that has a hydrophilic character. Purpose of $\mathrm{o} / \mathrm{w}$ microemulsion predicted can increase the effectiveness and bioavailability of $\beta$-carotene and other antioxidant substances in the mace extract to inhibit vitamin $\mathrm{C}$ photooxidation in beverage 
model systems. It also the reason of its low of inhibition effect in control samples. Inhibition Effect of $\beta$-carotene on photooxidation influenced by solvent type that used [1], [11]-[16] and its quenching activity will increase with following solvent hydrophobicity [7].

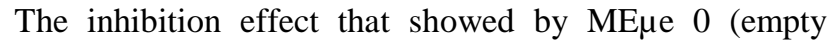
microemulsion), it is predicted caused by its role as a physical barrier in the systems. Oil-in-water microemulsion in aqueous systems have ability to form a thin film that can inhibit the contact between sensitiser, vitamin $\mathrm{C}$ and oxygen [14].

\section{B. Effect of Mace Extract Microemulsion to Inhibit Vitamin C Photooxidation in Apple Juice Beverage}

Effect of fluorescent light-illumination on vitamin $\mathrm{C}$ content of the apple juice beverage that contained mace extract microemulsion showed in Fig 3. The rate of vitamin $\mathrm{C}$ degradation is higher in samples stored under light condition than stored in dark condition (Table 2).

Based on the degradation of vitamin $\mathrm{C}$ that showed in Table 2. known that uses of mace extract microemulsion

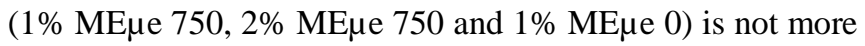
effective compared mace extract that uses directly (C-10 and $\mathrm{C}-15)$ in inhibiting photooxidation in the apple juice beverage under light condition $(\mathrm{P}<0.05)$. The commercial apple juice that used as the test system contains $1.31 \mathrm{mg} / \mathrm{L}$ riboflavin (35\% from DV to 2000 calories of energy needed). Riboflavin is one of sensitiser substances as well like erytrosin, chlorophyll, porfirin, myoglobin and metilene blue [1]-[24]. Reference [20] shows that all of vitamin C was loss after illuminated by light within 12 minutes in samples with 6 ppm riboflavin and only $2 \%$ that loss in samples without riboflavin. Moreover, riboflavin also predicted to fasten the vitamin $\mathrm{C}$ degradation caused by photooxidation with erytrosin $20 \mathrm{ppm}$ that has been added into the apple juice beverage system. This condition also causes the rate of vitamin $\mathrm{C}$ degradation in apple juice is higher than in beverage model systems under light condition (Table 1 and Table 2).

Degradation of vitamin $\mathrm{C}$ in apple juice beverage is very low in dark storage condition. Its decreasing rate is caused by autooxidation, and not by photooxidation. The rate of vitamin $\mathrm{C}$ degradation in apple juice beverage lower than beverage model systems at dark storage condition (Table 1 and Table 2). Apple juice beverage is a complex system more than beverage model systems. Naturally, apple juice containing vitamin $\mathrm{C}$, poliphenol, flavonoid that known as antioxidant substances [25]. Reference [26] shows that flavonoid compounds in apple are dihydrocalchones, phloridzin, phloretin, procyanidin B2 and epicatechin. Vitamin $C$ in the commercial apple juice that uses in this research is about $210.375 \mathrm{mg} / \mathrm{L}$ (85\% from DV to 2000 calorie of energy needed). Finally, inhibition on vitamin $\mathrm{C}$ degradation of apple juice beverage systems in dark storage condition is also influenced by its bioactive compounds, including vitamin $\mathrm{C}$.
(A)

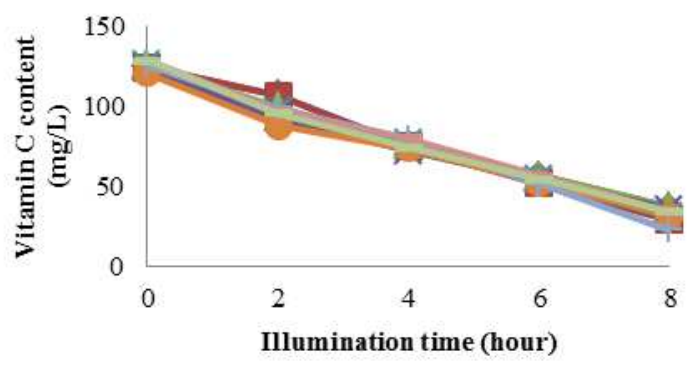

(B)

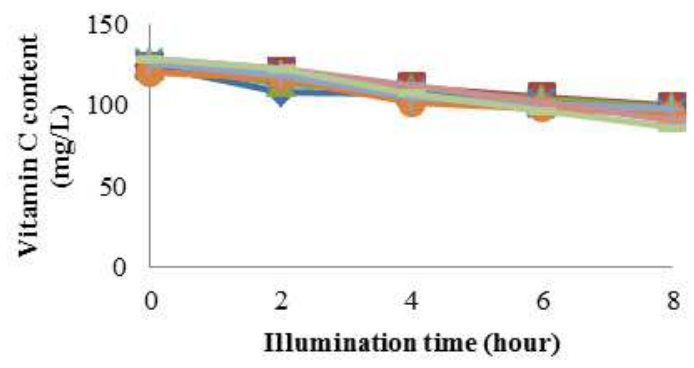

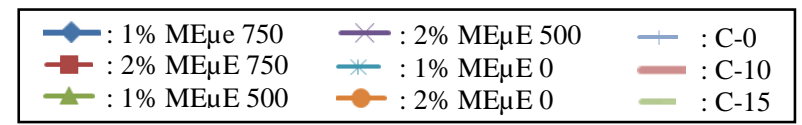

Fig. 3 The effect of fluorescent light-illumination on vitamin $\mathrm{C}$ content of apple juice beverage that contained mace extract microemulsion stored under light (A) and dark (B) condition.

TABLE III

INHIBITION EFFECT OF MACE EXTRACT MiCROEMULSION ON VitAMin C Photooxidation In Apple Juice Beverage

\begin{tabular}{|c|c|c|}
\hline \multirow{2}{*}{$\begin{array}{l}\text { Apple Juice Beverage } \\
\text { Sample }\end{array}$} & \multicolumn{2}{|c|}{$\begin{array}{c}\text { Rate of Vitamin C Degradation } \\
\text { (mg/L/hour) }\end{array}$} \\
\hline & Light (A) & Dark (B) \\
\hline 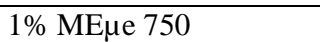 & $11.280 \pm 0.120^{\mathrm{c}}$ & $3.318 \pm 0.038^{\mathrm{ab}}$ \\
\hline 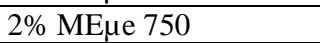 & $12.267 \pm 0.115^{\mathrm{e}}$ & $3.259 \pm 0.134^{\mathrm{ab}}$ \\
\hline $1 \%$ MEนе 500 & $11.003 \pm 0.055^{b}$ & $3.200 \pm 0.313^{\mathrm{a}}$ \\
\hline 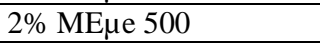 & $10.693 \pm 0.035^{\mathrm{a}}$ & $4.040 \pm 0.060^{\mathrm{e}}$ \\
\hline $1 \%$ MEนе 0 & $11.660 \pm 0.200^{\mathrm{d}}$ & $3.918 \pm 0.138^{\mathrm{de}}$ \\
\hline $2 \%$ МЕце 0 & $10.640 \pm 0.090^{\mathrm{a}}$ & $3.487 \pm 0.044^{\mathrm{bc}}$ \\
\hline $\mathrm{C}-0$ & $12.673 \pm 0.075^{f}$ & $3.712 \pm 0.138^{\mathrm{cd}}$ \\
\hline $\mathrm{C}-10$ & $11.507 \pm 0.105^{\mathrm{d}}$ & $4.856 \pm 0.006^{f}$ \\
\hline $\mathrm{C}-15$ & $11.463 \pm 0.185^{\mathrm{cd}}$ & $5.515 \pm 0.147^{g}$ \\
\hline
\end{tabular}

Different letters on the column were significant at 0.05 . Results are the mean \pm SD of at least three replicates.

\section{CONCLUSIONS}

The inhibition effect of mace extract microemulsion on vitamin $\mathrm{C}$ photooxidation in aqueous systems have been studied. Degradation of vitamin $\mathrm{C}$ causes by photooxidation only occur in samples that stored under light condition with presence of erytrosin as photosensitiser. Mace extract microemulsion has anti-photooxidation activity in samples that stored under light condition and it's effective to inhibit vitamin $\mathrm{C}$ degradation causes by photooxidation in aqueous systems, especially in the beverage model system. 


\section{REFERENCES}

[1] D. B. Min and J. M. Boff, "Chemistry and Reaction of Singlet Oxygen in Foods," J. Comprehensive Reviews in Food Science and Food Safety, vol. 1, pp. 58-72, 2002.

[2] J. Pokorny, N. Yanishlieva, M. Gordon, Antioxidant in Food, Cambridge-England: CRC Press, 2001.

[3] D. G. Bradley and D. B. Min, "Singlet Oxygen Oxidation of Foods," J. Crit. Rev. Food Sci. Nutr, vol. 31, pp. 211-236, 1992.

[4] J. H. Lee, "Photooxidation and Photosensitized Oxidation of Linoleic Acid, Milk, and Lard," Dissertation, The Ohio State University, Columbus, Ohio, USA, 2002.

[5] S. H. Lee and D. B. Min, "Effects, Quenching Mechanism and Kinetics of Carotenoids in Chlorophyll-Sensitized Photooxidation of Soybean Oil," J. Agric. Food Chem., vol. 38 (8), pp. 1630-1634, 1990.

[6] M. Y. Jung and D. B. Min, "Effects of Quenching Mechanisms of Carotenoids on the Photosensitized Oxidation of Soybean Oil," JAOCS., vol. 68 (9), pp. 653-658, 1991.

[7] M. Kobayashi and Y. Sakamoto, "Singlet Oxygen Quenching Ability of Astaxanthan Esters from The Green Alga Haematococcus Pluvialis," Biotech Lett., vol. 21, pp. 265-269, 1999.

[8] S. Beutner, B. Bloedorn, T. Hoffman and H. D. Martin, Synthetic Singlet Oxygen Quenchers. In: L. Packer, H. Sies, Ed., Methods In Enzymology, vol. 319, New York: Academic Press, pp. 226-241, 2000 .

[9] T. L. Li, J. M. King and D. B. Min, "Quenching Mechanism and Kinetics of Carotenoid in Riboflavin Photosensitized Singlet Oxigen Oxidation of Vitamin $\mathrm{D}_{2}$," J. Food Biochem., vol. 24 (6), pp. 477-492, 2000

[10] K. Viljanen, S. Susanna, O. Toshiaki and H. Marina, "Carotenoids as Antioxidants to Prevent Photooxidation,". Eur. J. Lipid Sci. Technol., vol. 104, pp. 353-359, 2002.

[11] W. T. Yang, J. H. Lee and D. B. Min, "Quenching Mechanism and Kinetics of $\alpha$-Tocopherol and $\beta$-Carotene on the Photosensitizing Effect of Synthetic Food Colorant FD\&C Red No. 3," J. Food Science, vol. 67 (2), pp. 507-510, 2002.

[12] H. M. C. De Azeredo, J. A. F. Faria and M. A. A. P. Da Silva, "The Efficiency of TBHQ, $\beta$-Carotene, Citric Acid, and Tinuvin $134^{\circledR}$ on The Sensory Stability of Soybean Oil Packaged in PET Bottles", J. Food Science vol. 68 (1), 2003.
[13] E. Choe and D. B. Min, "Mechanisms and Factors for Edible Oil Oxidation," J. Comprehensive Reviews In Food Science and Food Safety, vol. 5, pp.169-186, 2006.

[14] S. Ariviani, S. Raharjo and P. Hastuti, "The Potential Inhibition of $\beta$ Carotene Microemulsion in Vitamin C Photooxidation in Aqueous Systems," J. Teknologi dan Industri Pangan, Vol. 22 (1), pp. 33-38, 2011.

[15] M. A. Montenegro, M. A. Nazareno, E. N. Durantini and C. D. Borsarelli, "Singlet Molecular Oxygen Quenching Ability of Carotenoids in a Reverse-micelle Membrane Mimetic System," J. Photochemistry and Photobiology, vol. 75 (4), pp. 353-361, 2002.

[16] R. Edge, M. C. Garvey, and T. G. Truscott, "The Carotenoids as Antioxidants," A Review in J. Photochemistry and Photobiology B: Biology, vol. 41 (3), pp. 189-200, 1997.

[17] Sunanto, Budidaya Pala - Komoditas . Yogyakarta: Kanisius, 1993.

[18] J. Flanagan and H. Singh, "Microemulsions: A Potential Delivery System for Bioactive in Food," J. Crit. Rev. Food Sci. Nutr., vol. 4 , pp. 221-237, 2006.

[19] A. Spenarth, A. Yaghmur, A. Aserin, R. E. Hoffman and N. Garti, "Food-Grade Microemulsions Based on Nonionic Emulsifiers: Media to Enchance Lycopene Solubilization," J. Agric. Food Chem. vol. 50 (23), pp. 6917-6922, 2002.

[20] M. Y. Jung, S. K. Kim, and S. Y. Kim, "Riboflavin-Sensitized Photoxidation of Ascorbic Acid: Kinetics and Amino Acid Effects," J. Food Chem., vol. 53, pp. 397-403, 1995.

[21] E. C. Lee and D. B. Min, "Quenching Mechanism of $\beta$-Carotene on The Chlorophyll Sensitized Photooxidation of Soybean Oil," J. Food Sci., vol. 53 (6), pp. 1894-1895, 1988.

[22] O. Solomon, U. Svanberg and A. Sahlstrom, "Effect of Oxygen and Fluorescent Light on The Quality of Orange Juice During Storage at $8^{\circ}$ C," J. Food Chem., vol. 53, pp. 363-368, 1995.

[23] K. H. Lee, M. Y. Jung and S. Y. Kim, "Quenching Mechanism and Kinetics of Ascorbyl Palmitate for the Reduction of the Photosensitized Oxidation of Oils," JAOCS., vol. 74 (9), pp. $1053-$ 1057, 1997.

[24] S. Raharjo, Kerusakan Oksidatif pada Makanan, YogyakartaIndonesia: Gadjah Mada University Press, 2004.

[25] K. W. Lee, Y. J. Kim, D. O. Kim, H. J. Lee, and C. Y. Lee, "Major Phenolic in Apple and Their Cotribution to the Total Antioxidant Capacity," J. Agric. Food Chem., vol. 51, pp. 6516-6520, 2003.

[26] A. G. H. Lea, Flavor, Colour and Stability in Fruit Products: The Effects of Polyphenols. New York-USA: Plenum Press, p. 827-847, 1992 